\title{
PERAN DINAS KEBUDAYAAN DAN PARIWISATA DALAM PELESTARIAN KESENIAN WAYANG GOLEK DI KABUPATEN BANDUNG BARAT
}

\author{
Denis Abdul Azis'), Titin Rohayatin²), Zaenal Abidin AS') \\ 1), 2), 3)Prodi Ilmu Pemerintahan, Fakultas Ilmu Sosial dan Ilmu Politik, \\ Universitas Jenderal Achmad Yani Cimahi - Bandung
}

\begin{abstract}
Abstrak
Kesenian Wayang Golek merupakan kesenian yang berasal dari Provinsi Jawa Barat. Akibat perkembangan jaman, kesenian Wayang Golek mengalami penurunan pada paguyubannya, khususnya yang berada di daerah Kabupaten Bandung Barat. Untuk itu perlu ada upaya pelestarian yang dilakukan oleh Pemerintah Kabupaten Bandung Barat. Wayang Golek sendiri sudah diakusi oleh UNESCO sebagai Masterpiece of the Oral and Intangible Heritage of Humanity. Penelitian ini menggunakan metode deskriptif dengan pendekatan kualitatif, dengan informan 2 orang, yaitu : (1) Kepala Seksi Bina Seni Dinas Kebudayaan dan Pariwisata Kabupaten Bandung Barat,(2) dan Seniman Wayang Golek. Teknik pengumpulan data melalui wawancara, dokumentasi, dan observasi lapangan. Hasil penelitian menunjukan bahwa pelestarian kesenian Wayang Golek yang dilakukan Dinas Kebudayaan dan Pariwisata Kabupaten Bandung Barat dapat dikatakan belum optimal. Hal tersebut dikarenakan (1) belum adanya regulasi yang secara khusus mengatur tentang upaya pelestarian kesenian Wayang Golek (2) pemberdayaan yang dilakukan belum mampu meningkatkan partisipasi masyarakat dalam pelestarian kesenian Wayang Golek (3) belum optimal dalam menyediakan fasilitas berupa sarana dan prasarana penunjang dalam upaya pelestarian kesenian Wayang Golek.
\end{abstract}

Kata Kunci: Peran, Pemerintah, Pelestarian Kesenian, Wayang Golek

\begin{abstract}
Wayang Golek art is an art originating from West Java Province. Due to the development of the times, the Wayang Golek art has decreased in its association, especially in the West Bandung Regency area. For this reason, there need to be conservation efforts carried out by the West Bandung Regency Government. Wayang Golek itself has been accepted by UNESCO as a Masterpiece of the Oral and Intangible Heritage of Humanity. This study used a descriptive method with a qualitative approach, with 2 informants, namely: (1) Head of Section for Art Development of the Culture and Tourism Office of West Bandung Regency, (2) and Wayang Golek Artists. Data collection techniques through interviews, documentation, and field observations. The results showed that the preservation of Wayang Golek art by the West Bandung Regency Culture and Tourism Office was not optimal. This is because (1) no regulation specifically regulates efforts to preserve the art of puppet show (2) the empowerment has not been able to increase community participation in preserving the art of Wayang Golek (3) has not been optimal in providing facilities in the form of supporting facilities and infrastructure in effort preservation of the puppet show art.
\end{abstract}

Keywords: Role, Government, Art Preservation, Wayang Golek 


\section{PENDAHULUAN}

Undang-Undang Nomor 23 Tahun 2014 Tentang Pemerintahan Daerah yang tertuang dalam Pasal 1 Ayat 6 menerangkan bahwa "otonomi daerah merupakan hak, wewenang, dan kewajiban daerah otonom untuk mengatur dan mengurus sendiri urusan pemerintahan dan kepentingan masyarakat setempat dalam sistem Negara Kesatuan Republik Indonesia”. Pelaksanaan otonomi daerah selain berlandaskan pada acuan hukum, juga sebagai implementasi tuntutan globalisasi yang harus diberdayakan dengan cara memberikan daerah kewenangan yang lebih luas, lebih nyata dan bertanggung jawab, terutama dalam mengatur, memanfaatkan dan menggali sumbersumber potensi yang ada di daerah masing-masing. Pelaksanaan otonomi daerah merupakan titik fokus yang penting dalam rangka memperbaiki kesejahteraan rakyat, pengembangan suatu daerah dapat disesuaikan oleh Pemerintah Daerah dengan potensi dan kekhasan daerah masing-masing.

Asas desentralisasi dalam otonomi daerah memberikan dampak positif bagi perkembangan Bangsa Indonesia, salah satunya dari segi sosial budaya akan memperkuat ikatan sosial budaya pada suatu daerah. Karena dengan diterapkannya sistem desentralisasi ini Pemerintahan Daerah akan dengan mudah untuk mengembangkan kebudayaan yang dimiliki oleh daerah tersebut. Menurut Koentjaraningrat (1994:204) “terdapat tujuh unsur kebudayaan yaitu bahasa, kesenian, sistem religi, sistem teknologi, sistem mata pencaharian, organisasi sosial, dan sistem ilmu pengetahuan." Dengan hal ini kebudayaan tersebut dapat dikembangkan dan diperkenalkan kepada daerah lain. Yang nantinya merupakan salah satu potensi daerah tersebut.

Pemerintah Pusat melalui otonomi daerah memberi wewenang kepada Pemerintah Daerah sepenuhnya untuk mengatur rumah tangganya sendiri termasuk dalam hal pelestarian kesenian daerah sebagai salah satu unsur dari kebudayaan, melalui perangkat daerah yaitu Dinas Kebudayaan dan Pariwisata yang ada di daerah. Kabupaten Bandung Barat merupakan Kabupaten yang berada di Provinsi Jawa Barat yang beragam akan kesenian daerahnya, salah satunya adalah kesenian Wayang Golek. Dalam hal yang mengurusi kesenian khususnya pelestarian kesenian Wayang Golek 
Pemerintah Kabupaten Bandung Barat memberikan beban tugas kepada Dinas Kebudayaan dan Pariwisata. Pelestarian tersebut dilakukan untuk mencegah kepunahan dari kesenian Wayang Golek seiring dengan perkembangan zaman. Hal ini juga mengacu kepada mengacu kepada Peraturan Daerah Provinsi Jawa Barat Nomor 15 Tahun 2014 Tentang Pemeliharaan Kesenian yang menjelaskan bahwa : "Pada pasal 1 angka 6 bahwa : pemeliharaan adalah upaya dalam melakukan perawatan, pewarisan, dan untuk mencegah dan/atau menanggulangi kepunahan dan pengurangan nilai-nilai seni serta apresiasi karya seni dan penghargaan kepada seniman dan/atau pelaku seni; kemudian Pasal 1 6a: pelestarian adalah upaya dinamis untuk mempertahankan keberadaan kesenian dan nilai-nilainya dengan cara melindungi, mengembangkan, dan memanfaatkan."

Dalam program pelestarian di bidang kesenian Dinas Kebudayaan dan Pariwisata Kabupaten Bandung Barat setiap tahun dengan adanya pendataan mengenai lingkung seni Wayang Golek mana saja yang berada di Kabupaten Bandung Barat. Lingkung seni Wayang Golek yang berada di Kabupaten Bandung Barat dapat dilihat dalam tabel berikut:

Tabel 1

Data Lingkung Seni Wayang Golek Tahun 2012-2017 Di Kabupaten Bandung Barat

\begin{tabular}{|c|c|}
\hline No. & Nama Lingkung Seni Wayang Golek \\
\hline 1 & Lingkung Seni Wayang Golek Pancanaka \\
\hline 2 & Lingkung Seni Manduraharja \\
\hline 3 & Lingkung Seni Giri Wibawa 1 \\
\hline 4 & Lingkung Seni Gumelar Raharja \\
\hline 5 & Lingkung Seni Wayang Golek Jenggala Manik \\
\hline
\end{tabular}

Sumber: Hasil Olahan Peneliti 2017 
Berdasarkan tabel di atas menunjukkan bahwa kesenian Wayang Golek yang ada di Kabupaten Bandung Barat sangat sedikit. Akan tetapi, disini peran Dinas Kebudayaan dan Pariwisata masih belum optimal dalam hal pelestarian kesenian Wayang Golek dengan adanya lingkung seni Wayang Golek yang masih kurang diperhatikan terhadap pengembangannya dan pendataan lingkung seni tersebut. Oleh karena itu disini diperlukan adanya suatu peran. Menurut Rivai (2006: 148) "Peran diartikan sebagai perilaku yang diatur dan diharapkan dari seseorang dalam posisi tertentu untuk melaksanakan hak-hak dan kewajiban”. Artinya disini Dinas Kebudayaan dan Pariwisata dalam melaksanakan hak dan kewajibannya sesuai dengan tugas pokok dan fungsinya harus menjalankan suatu peran.

Fenomena yang terjadi saat ini keberadaan pagelaran Wayang Golek kian menurun setiap tahunnya, dikarenakan belum optimalnya pengembangan serta pelestarian terhadap kesenian Wayang Golek. Dapat dilihat dari penurunan setiap tahunnya dalam grafik berikut:

\section{Grafik 1}

\section{Eksistensi Pagelaran Wayang Golek Di Kabupaten Bandung Barat}

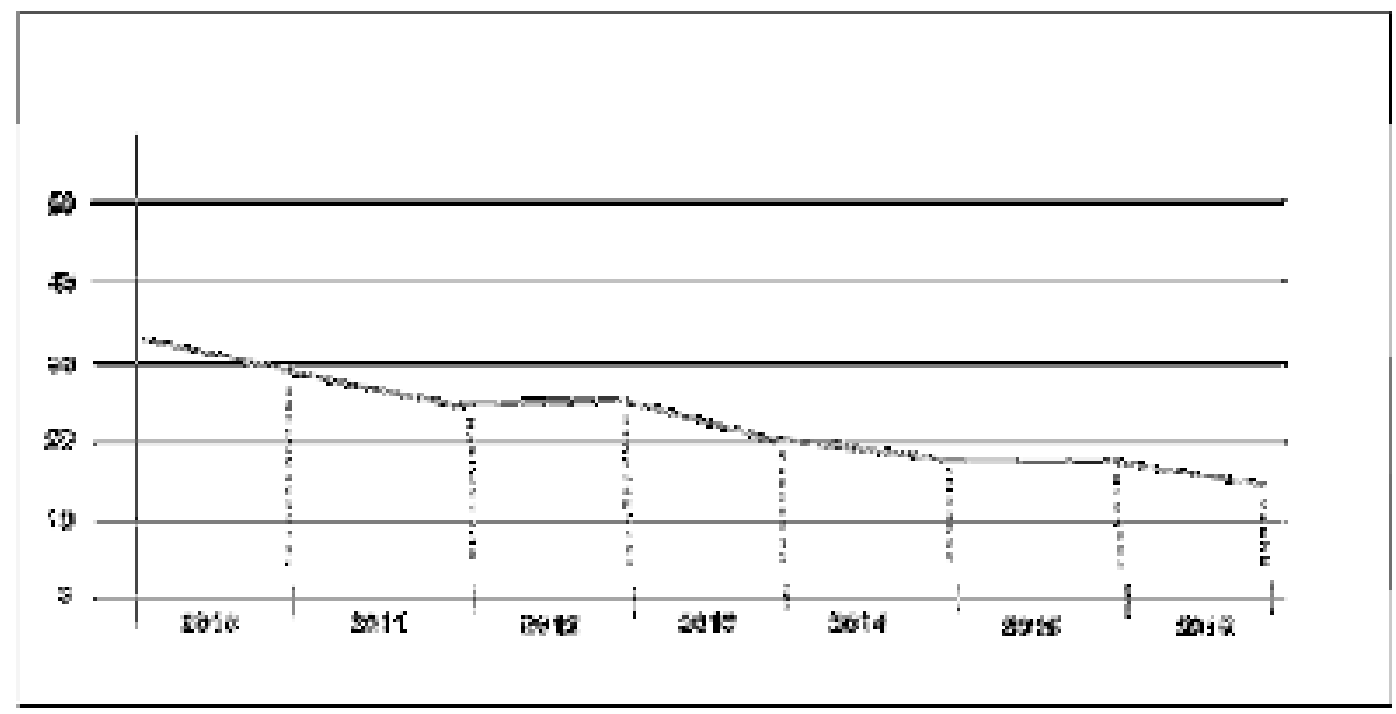

Sumber: Hasil Olahan Peneliti 2017

Dari grafik di atas dapat dilihat bahwa eksistensi pagelaran Wayang Golek di Kabupaten Bandung Barat setiap tahunnya terjadi penurunan dari tahun 2013 ke tahun 2016, hal ini dikarenakan kurangnya dukungan dari Pemerintah untuk menyelenggarakan pagelaran Wayang Golek serta minimnya 
promosi yang dilakukan. Lalu ditahun 2012 terdapat kenaikan persentase tetapi belum terlalu signifikan.

Seperti yang dilansir dari website bharatanews.id penyebab dari menurunnya pagelaran Wayang Golek sendiri ditandai dengan kurangnya fasilitas-fasilitas pendukung pagelaran baik alat-alat keseniannya maupun boneka wayangnya, serta kurangnya promosi dari Dinas Kebudayaan dan Pariwisata akan keberadaan kesenian Wayang Golek yang berada di Kabupaten Bandung Barat, dan kurangnya minat dari masyarakat terutama generasi muda akan kesenian Wayang Golek. Kabupaten Bandung Barat yang memiliki potensi akan kebudayaannya serta mempunyai beragam kesenian di setiap daerahnya. Akan tetapi, masih kurang perhatiannya terhadap pengembangan serta pelestarian kesenian Wayang Golek, belum optimalnya peran dari Dinas Kebudayaan dan Pariwisata untuk memfasilitasi pagelaran Wayang Golek.

\section{METODE PENELITIAN}

Penelitian ini bertujuan untuk mendapatkan informasi secara tepat dan gambaran yang lengkap dan faktual mengenai Peran Dinas Kebudayaan dan Pariwisata dalam melakukan pelestarian kesenian Wayang Golek di Kabupaten Bandung Barat. Peneliti berusaha menggali dan menginterpresentasikan fenomena yang berkembang. Dan untuk melihat kondisi alam dari suatu fenomena. Pendekatan penelitian yang digunakan dalam penelitian ini adalah pendekatan kualitatif. Pendekatan ini memperoleh pemahaman dan penggambaran realitas yang kompleks. Penelitian ini bertujuan untuk menggambarkan Peran Dinas Kebudayaan dan Pariwisata dalam melestarikan Kesenian Wayang Golek di Kabupaten Bandung Barat. Dengan mengadakan kegiatan-kegiatan pagelaran kesenian Wayang Golek.

\section{PEMBAHASAN}

\section{Peran Dinas Kebudayaan dan Pariwisata Dalam Pelestarian Kesenian Wayang Golek di Kabupaten Bandung Barat}

Pelestarian kesenian merupakan upaya yang sangat penting untuk diwujudkan dalam rangka meningkatkan eksistensi kesenian pada suatu 
daerah. Pemerintah merupakan organ yang memiliki kewajiban dalam upaya melestarikan kesenian tersebut. Berbagai upaya yang dilakukan Pemerintah diimplikasikan melalui berbagai elemen pemerintahan yang bergerak didalam bidangnya masing- masing. Dinas Kebudayaan dan Pariwisata adalah organ yang ditunjuk sebagai elemen yang memiliki kewenangan dan tanggungjawab dalam upaya melestarikan kesenian ditingkat daerah. Berbagai kesenian di dalam suatu daerah merupakan modal yang penting bagi pembangunan.

Peran Dinas Kebudayaan dan Pariwisata dalam melestarikan kesenian sangat urgent adanya mengingat arus globalisasi dan modernisasi yang semakin kuat kian mengikis berbagai ciri khas dan kepribadian bangsa. Salah satu kesenian yang kian menyurut keberadaannya adalah kesenian wayang golek. Wayang golek merupakan salah satu kesenian yang sangat khas di Bandung Barat. Dinas Kebudayaan dan Pariwisata Kabupaten Bandung Barat memiliki peran yang sangat vital dalam melestarikan kesenian wayang golek tersebut.Peran Dinas Kebudayaan dan Pariwisata Kabupaten Bandung Barat dikemukakan dalam Peraturan Bupati Bandung Barat Nomor 19 Tahun 2009 tentang tugas pokok dan fungsi Dinas Kebudayaan dan Pariwisata Pasal 9 ayat (3) yakni:

(a) Melaksanakan penyusunan dan analisis data bahan penetapan kriteria dan prosedur penyelenggaraan festival, pameran, dan lomba di bidang seni;

(b) Melaksanakan penyusunan dan analisis data bahan kegiatan pendidikan dan pelatihan kesenian;

(c) Melaksanakan penyusunan dan analisis data bahan perlindungan, pengembangan dan pemanfaatan kesenian.

Upaya pelestarian kesenian wayang golek di Kabupaten Bandung Barat dapat dilakukan melalui berbagai bentuk kegiatan ataupun program, seperti festival, pameran, lomba, pendidikan, pelatihan dan lain sebagainya. Dinas Kebudayaan dan Pariwisata Kabupaten Bandung Barat harus mampu menjalankan perannya dengan optimal agar upaya pelestarian kesenian wayang golek pun dapat memberikan hasil yang maksimal pula. Tujuan dari upaya pelestarian kesenian wayang golek oleh Dinas Kebudayaan dan Pariwisata Kabupaten Bandung Barat tentu diwujudkan dalam rangka meningkatkan eksistensi kesenian wayang golek yang juga akan memberikan 
hasil pada meningkatnya persatuan daerah, ciri khas dan kepribadian bangsa juga dapat berimplikasi pada meningkatkannya pendapatan daerah dibidang kesenian.

Untuk dapat menjelaskan bagaimana peran Dinas Kebudayaan dan Pariwisata Kabupaten Bandung Barat, peneliti menjabarkannya melalui beberapa dimensi yakni :

1. Pemerintah sebagai regulator, dengan indikator:

a. Peraturan Pelestarian Kesenian

2. Pemerintah sebagai dinamisator, dengan indikator:
a. Menggerakan partisipasi masyarakat
b. Pemberian sosialisasi dan pembinaan

3. Pemerintah sebagai fasilitator, dengan indikator:
a. Pembangunan untuk pelestarian
b. Mengembangkan potensi

Dalam menjelaskan bagaimana peran Dinas Kebudayaan dan Pariwisata Kabupaten Bandung Barat dalam melestarikan kesenian wayang golek, peneliti melakukan wawancara serta observasi, berikut hasil wawancara dan observasi tersebut peneliti kemukakan dalam pembahasan pada subbab dibawah ini.

\section{Pemerintah Sebagai Regulator}

Pemerintah sebagai regulator bertindak sebagai elemen yang bertanggungjawab dalam menetapkan arah dan tujuan daripada kegiatankegiatan yang dilaksanakan melalui suatu regulasi. Berbagai regulasi dalam upaya melestarikan kesenian telah dibuat dan diimplementasikan dari hirarki pemerintah pusat hingga ke hirarki daerah. Keberadaan regulasi tentu diimplementasikan agar segala tujuan pelestarian kesenian dapat sesuai dengan apa yang telah ditetapkan sebelumnya. Regulasi memuat berbagai upaya yang dilakukan dalam rangka melestarikan kesenian dan siapa yang bertanggungjawab dalam melestarikan kesenian tersebut. Regulasi dibuat untuk kemudian di implementasikan oleh organ pemerintahan yang berwenang.

Dinas Kebudayaan dan Pariwisata Kabupaten Bandung Barat diberikan wewenang dalam melaksanakan berbagai upaya pelestarian yang ditetapkan melalui berbagai regulasi termasuk dalam hal ini adalah pelestarian kesenian 
wayang golek yang menjadi ciri khas Kabupaten Bandung Barat. Regulasi tersebut adalah :

1. Peraturan Daerah Provinsi Jawa Barat Nomor 15 Tahun 2014 Tentang Perubahan Atas Peraturan Daerah Provinsi Jawa Barat Nomor 6 Tahun 2003 Tentang Pemeliharaan Kesenian.

2. Peraturan Daerah Kabupaten Bandung Barat Nomor 4 Tahun 2012 Tentang Rencana Induk Pembangunan Kepariwisataan Kabupaten Bandung Barat.

Melalui berbagai regulasi yang telah ditetapkan dan di implementasikan sebagai acuan kerja Dinas Kebudayaan dan Pariwisata dalam upaya pelestarian kesenian wayang golek, maka peneliti dapat memahami lebih mudah bagaimana seharusnya Dinas Kebudayaan dan Pariwisata dalam menjalankan peran dan fungsinya. Dan peneliti juga dapat melihat berbagai kesenjangan yang terjadi dalam pelaksanaan peran tersebut.

\section{a. Peraturan Pelestarian Kesenian}

Dalam sebuah penyelenggaraan Pemerintahan tentunya terdapat sebuah peraturan yang dimana peraturan merupakan perangkat yang berisi patokan dan ketentuan untuk dijadikan pedoman yang merupakan hasil dari keputusan yang telah disepakati dalam suatu instansi/organisasi yang bersifat mengikat, membatasi, dan mengatur dan harus ditaati serta harus dilakukan untuk mencapai tujuan yang telah ditetapkan. Pelestarian kesenian wayang golek yang diselenggarakan oleh Dinas Kebudayaan dan Pariwisata dalam rangka mengembangkan, meningkatkan eksistensi serta mencegah terjadinya kepunahan tentunya harus mempunyai sebuah peraturan agar dalam pelestarian kesenian wayang golek tersebut dapat terealisasi secara maskimal dan menanggulangi permasalahan-permasalahan yang ada terkait pengembangan dan pelestarian kesenian wayang golek yang ada di Kabupaten Bandung Barat. Dalam suatu peraturan tersebut peran Dinas Kebudayaan dan Pariwisata Kabupaten Bandung Barat dalam 
penyelenggaraan pelestarian kesenian wayang golek diinterpretasikan melalui beberapa program.

Berikut program-program pengembangan dan pelestarian kesenian wayang golek yang peneliti peroleh dari Renstra Dinas Kebudayaan dan Pariwisata Kabupaten Bandung Barat 2013-2018, diantaranya :

1. Meningkatkan pengembangan kesenian

2. Mewujudkan penyediaan sarana dan prasarana yang representatif sebagai pendukung pelestarian kesenian

3. Meningkatkan pelestarian kesenian

4. Pendataan dan pendokumentasian jumlah grup/kelompok kesenian.

Berdasarkan hasil wawancara bersama Bapak Usup selaku Kepala Seksi Bina Seni menjelaskan bahwa:

"Dinas Kebudayaan dan Pariwisata melakukan upaya pelestarian kesenian wayang golek yang diawali dengan pendataanpendataan lingkung seni wayang golek yang ada di Bandung Barat untuk kemudian dilakukan langkah konkret untuk menanggulangi permasalahan menurunnya eksistensi pagelaran kesenian wayang golek yang ada di Bandung Barat.Regulator dalam upaya penyelenggaraan pelestarian kesenian wayang golek secara teknis di Bandung Barat masih mengacu pada Peraturan Daerah Provinsi Jawa Barat Nomor 15 Tahun 2014 tentang Perubahan Atas Peraturan Daerah Provinsi Jawa Barat Nomor 6 Tahun 2003 tentang Pemeliharaan Kesenian, karena Bandung Barat belum memiliki regulator secara khusus membahas tentang bagaimana upaya pelestarian kesenian wayang golek dilakukan. Meskipun ada Peraturan Daerah Kabupaten Bandung Barat, itu juga hanya sekedar rencana induk yang tidak berkaitan secara langsung dengan pemeliharaan kesenian, melainkan berkaitan dengan kepariwisataan, yakni Peraturan Daerah Nomor 4 Tahun 2012 tentang Rencana Induk PembangunanKepariwisataan."

Penjelasan tentang upaya pelestarian kesenian yang termuat dalam Peraturan Daerah Kabupaten Bandung Barat Nomor 4 Tahun 2012 tentang Rencana Induk Pembangunan Kepariwisataan terdapat pada pasal 52, yakni: Pengembangan kesenian sebagaimana dimaksud dalam pasal 51 huruf a, dilakukan melalui: huruf (a) pendataan, pencatatan, pendokumentasian keanekaragaman kesenian daerah baik yang telah punah, hampir punah dan yang saat ini keberadaannya masih hidup di tengah-tengah masyarakat; kemudian huruf (b) pemeliharaan, perlindungan, dan pengembangan kesenian yang hidup ditengah-tengah masyarakat untuk pengembangan kepariwisataan. 
Saat ini Dinas Kebudayaan dan Pariwisata Kabupaten Bandung Barat masih mengacu pada Peraturan Daerah Kabupaten Bandung Barat Nomor 4 Tahun 2012 tentang Rencana Induk Pembangunan Kepariwisataan dan Peraturan Daerah Provinsi Jawa Barat Nomor 15 Tahun 2014 Tentang Perubahan Atas Peraturan Daerah Provinsi Jawa Barat Nomor 6 Tahun 2003 Tentang Pemeliharaan Kesenian, dalam upaya mengembangkan dan melestarikan kesenian wayang golek.

Belum adanya Peraturan Daerah Kabupaten Bandung Barat yang secara khusus mengatur tentang bagaimana upaya pelestarian kesenian wayang golek, menimbulkan munculnya permasalahan dalam pengembangan dan pelestarian kesenian wayang golek yang telah dilakukan. Observasi yang peneliti lakukan dilapangan menemukan beberapa penemuan-penemuan terkait berupa permasalahan-permasalahan yang ditunjukan dengan kurang optimalnya pelestarian wayang golek yang diselenggarakan setiap tahunnya oleh Dinas Kebudayaan dan Pariwisata Kabupaten Bandung Barat. Hal tersebut dapat dilihat melalui data tabel berikut:

Tabel 2

Jumlah Group dan Pagelaran Wayang Golek di Kabupaten Bandung Barat

\begin{tabular}{|c|c|c|c|}
\hline \multirow{2}{*}{ Keterangan } & \multicolumn{3}{|c|}{ Tahun } \\
\cline { 2 - 4 } & $\mathbf{2 0 1 5}$ & $\mathbf{2 0 1 6}$ & $\mathbf{2 0 1 7}$ \\
\hline $\begin{array}{c}\text { Jumlah Group } \\
\text { Kesenian } \\
\text { Wayang Golek }\end{array}$ & 5 & 5 & 3 \\
\hline $\begin{array}{c}\text { Jumlah } \\
\text { Pagelaran } \\
\text { Wayang Golek }\end{array}$ & 16 & 14 & 12 \\
\hline
\end{tabular}




\section{Sumber: Dinas Kebudayaan dan Pariwisata Kabupaten Bandung Barat, 2017}

Berdasarkan pada tabel tersebut, menunjukan bahwa jumlah group kesenian wayang golek yang terbentuk mempengaruhi pada jumlah pagelaran wayang golek setiap tahunnya. Setiap tahun jumlah pagelaran wayang golek semakin menurun, hal tersebut menunjukan bahwa Dinas Kebudayaan dan Pariwisata Kabupaten Bandung Barat belum menjalankan perannya dengan optimal. Jumlah group kesenian pada tahun 2015, 2016 masih terdapat 5 group tetapi pada tahun 2017 menjadi 3 group kesenian yakni group kesenian wayang golek tersebut :

1. Lingkung Seni Wayang Golek Pancanaka

2. Lingkung Seni Manduraharja

3. Lingkung Seni Giri Wibawa 1

Menurut hasil wawancara dan observasi peneliti dilapangan serta dimensi regulator, dapat dilihat bahwa peran yang dijalankan oleh Dinas Kebudayaan dan Pariwisata Kabupaten Bandung Barat kurang optimal jika tidak didukung dengan adanya regulasi teknis tentang bagaimana upaya pelestarian kesenian wayang golek yang ada di Bandung Barat. Sehingga pada dasarnya, regulasi merupakan salah satu syarat yang harus ada agar pencapaian tujuan dapat memberikan hasil yang maksimal.Penyelenggaraan pelestarian kesenian wayang golek tak hanya mengandalkan pada quality para pelaksananya, melainkan ditentukan oleh keberadaan regulasi yang mengatur tata cara pelaksanaannya.

Pemerintah Kabupaten Bandung Barat harus menyiapkan arah dan tujuan untuk merancang sebuah regulasi mengenai pelestarian kesenian wayang golek agar Dinas Kebudayaan dan Pariwisata dapat memiliki acuan peraturan daerah sendiri yang dapat meningkatkan kinerja peran Dinas Kebudayaan dan Pariwisata dengan modal dasar atau aset yang sangat penting dan strategis untuk mengembangakn pariwisata melalui pelestarian kesenian wayang golek. Dalam penyelenggaraan yang telah dilakukan oleh Dinas Kebudayaan dan Pariwisata mengenai pelestarian kesenian wayang golek terdapat 2 group kesenian wayang golek yang hilang dikarenakan minimnya pagelaran wayang golek di Bandung Barat dan minimnya sarana dan prasarana yang ada mengakibatkan hilangnya group kesenian wayang 
golek.

\section{Pemerintah Sebagai Dinamisator}

Peran pemerintah sebagai dinamisator adalah menggerakan partisipasi masyarakat jika terjadi kendala-kendala dalam proses pembangunan untuk mendorong dan memelihara dinamika pembangunan daerah. Dinas Kebudayaan dan Pariwisata Kabupaten Bandung Barat berperan memberikan bimbingan dan pengarahan secara intensif dan efektif kepada masyarakat. Kegiatan ini dilakukan oleh Dinas Kebudayaan dan Pariwisata Bandung Barat dengan cara berkoordinasi dengan PEPADI (Persatuan Pedalangan Indonesia).

Dinas Kebudayaan dan Pariwisata Kabupaten Bandung Barat berperan dalam menggerakkan masyarakat untuk ikut berpartisipasi dalam upaya pelestarian kesenian wayang golek di Kabupaten Bandung Barat. Dimensi pemerintah sebagai dinamisator ini mencukup dua indikator yakni:

1. Menggerakan partisipasi masyarakat, dan

2. Pemberian sosialisasi dan pembinaan.

Berikut hasil penelitian dari dua indikator tersebut peneliti jabarkan pada sub bab dibawah ini.

a. Menggerakan Partisipasi Masyarakat

Pada indikator menggerakan partisipasi masyarakat ini, Dinas Kebudayaan dan Pariwisata Kabupaten Bandung Barat berperan melakukan sosialisasi mengenai pengembangan dan pelestarian kesenian wayang golek yang dimulai dari tingkat desa dan kecamatan. Dalam rangka meningkatkan partisipasi masyarakat ini, Dinas Kebudayaan dan Pariwisata Kabupaten Bandung Barat senantiasa menyelenggarakan event dengan peserta yang berasal dari berbagai padepokan kesenian wayang golek serta masyarakat di daerah tersebut.

Partisipasi masyarakat merupakan modal utama yang dibutuhkan dalam rangka melestarian kesenian wayang golek di Kabupaten Bandung Barat. Untuk mengetahui bagaimana upaya Dinas Kebudayaan dan Pariwisata Kabupaten Bandung Barat dalam menggerakan partisipasi masyarakat, peneliti melakukan wawancara dengan Bapak Usup, beliau menjelaskan bahwa:

"Dinas Kebudayaan dan Pariwisata Kabupaten Bandung Barat telah melakukan sosialisasi kepada masyarakat dengan kunjungan ke beberapa kecamatan dan desa melaksanakan 
bimtek kunjungan kerja dan sosialisasi. Tujuan dari sosialisasi ini adalah untuk memberikan pengarahan kepada masyarakat tentang betapa pentingnya upaya pelestarian kesenian wayang golek. Selain itu, sosialisasi juga dilakukan untuk melakukan koordinasi terhadap penyelenggaraan pagelaran wayang golek yang akan dilaksanakan kedepannya."

Dalam pemberian sosialisasi kepada masyarakat Dinas Kebudayaan dan Pariwisata melakukan kunjungan ke beberapa kecamatan dan desa untuk melaksanakan bimbingan teknis serta kunjungan kerja setiap Tri Wulannya, disamping itu Dinas Kebudayaan dan Pariwisata menjelaskan kepada masyarakat pentingnya pelestarian kesenian wayang golek agar tidak terancam punah. Dinas Kebudayaan dan Pariwisata menyiapkan formulir lingkung seni apabila terdapat group kesenian wayang golek yang belum terdata serta menerima saran dan masukan dari masyarakat dalam upaya pengembangan dan pelestarian kesenian yang dilakukan. Hasil observasi yang peneliti lakukan pada salah satu pagelaran wayang golek di Kecamatan Ngamprah Kabupaten Bandung Barat memperlihatkan bahwa partisipasi masyarakat masih sangatlah rendah. Hal tersebut dapat dilihat pada gambar berikut:

\section{Gambar 1 \\ Partisipasi Masyarakat dalam Pagelaran Wayang Golek di Kabupaten Bandung Barat}

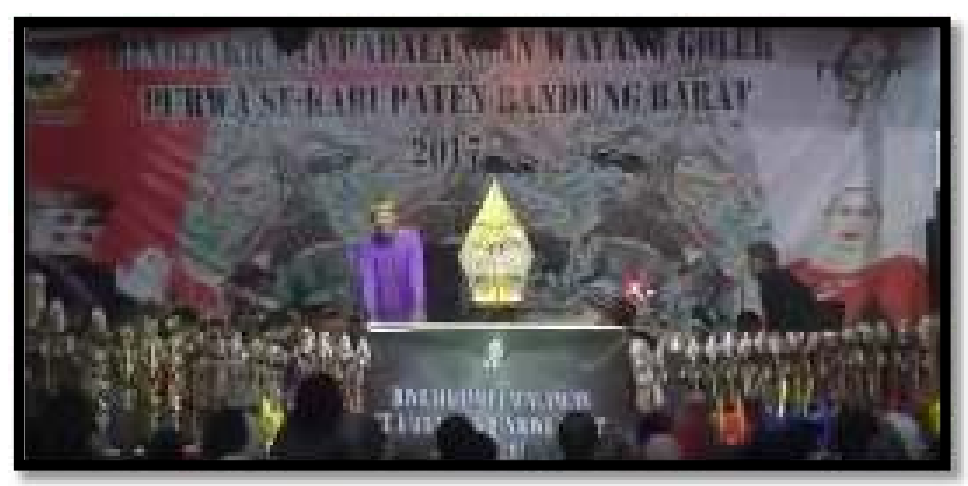

Antusias masyarakat dalam menonton pagelaran wayang golek pun masih cukup minim, meskipun dalam hal ini salah satu alasannya adalah karena pagelaran wayang golek selalu dilakukan pada malam hari. Kegiatan yang telah dilaksanakan oleh Dinas Kebudayaan dan Pariwisata Kabupaten Bandung Barat belum sesuai dengan rencana yang telah ditetapkan. Peran Dinas Kebudayaan dan Pariwisata Kabupaten Bandung Barat baru sebatas menggugurkan kewajiban dalam pemberian sosialisasi, belum berupaya untuk mencapai hasil yang signifikan. Sehingga dalam hal ini dapat diketahui bahwa 
tingkat partisipasi masyarakat sangat mempengaruhi peran Dinas Kebudayaan dan Pariwisata dalam menjalankan tugas dan fungsinya.

Peneliti melihat bahwa dalam menggerakkan partisipasi masyarakat Dinas Kebudayaan dan Pariwisata sebagai dinamisator harus dapat menarik perhatian masyarakat dengan adanya gelar seni seperti pameran, festival kesenian, dan pasanggiri.

Dalam pelaksanaannya Dinas Kebudayaan dan Pariwisata dapat memberikan pengarahan dan informasi langsung kepada masyarakat agar bersama-sama berupaya dalam melestarikan kesenian wayang golek. Maka dengan meningkatnya partisipasi masyarakat Dinas Kebudayaan dan Pariwisata dapat lebih optimal dengan menyusun strategis pengembangan dan pelestarian kesenian wayang golek.

b. Pemberian Sosialisasi dan Pembinaan

Dinas Kebudayaan dan Pariwisata Kabupaten Bandung Barat telah senantiasa melakukan sosialisasi dan pembinaan dalam upaya pelestarian kesenian wayang golek. Sosialisasi dilakukan pada masyarakat Bandung Barat untuk membuka pemahaman serta pola pikir masyarakat bahwa betapa pentingnya upaya pelestarian kesenian wayang golek.

Masyarakat yang paham dan mengerti akan membantu realisasi program yang diimplementasikan oleh Dinas Kebudayaan dan Pariwisata Kabupaten Bandung Barat. Tak hanya sosialisasi saja, Dinas Kebudayaan dan Pariwisata Kabupaten Bandung Barat pun sering melakukan pembinaan kepada para seniman wayang golek dengan tujuan agar seniman-seniman tersebut tetap konsisten dalam mengembangkan, menjaga serta melestarikan kesenian wayang golek. Pembinaan tak hanya sekedar sampai pada seniman saja, Dinas Kebudayaan dan Pariwisata Kabupaten Bandung Barat berharap agar seniman juga melakukan pendekatan serta sosialisasi sekunder pada masyarakat tentang upaya pelestarian kesenian wayang golek. Berdasarkan hasil wawancara peneliti dengan Bapak Usup selaku Kepala Bina Seni Dinas Kebudayaan dan Pariwisata Kabupaten Bandung Barat mengatakan bahwa:

"Sosialisasi dan pembinaan sering kami lakukan pada para seniman. Kerjasama terus kami tingkatkan dengan Pepadi-KBB agar seniman Bandung Barat semakin terbuka pola pikirnya untuk membentuk grup-grup kesenian wayang golek yang baru. Hal ini bertujuan agar kesenian wayang golek tidak punah dengan adanya arus globalisasi yang semakin kuat. Kami berharap kerjasama ini dapat terjalin dengan baik, dan masyarakat juga bisa diajak berkoordinasi dengan baik pula." 
Sementara itu, peneliti pun melakukan wawancara dengan Bapak Cep Syahroni selaku seniman wayang golek, yang menjelaskan bahwa:

"Dinas Kebudayaan dan Pariwisata sudah jarang sekali melakukan sosialisasi, dalam setahun hanya terhitung beberapa kali. Mengenai Pepadi, pepadi sering melakukan pembinaan dalang yang tersebar di beberapa titik daerah di Kabupaten Bandung Barat".

Berdasarkan data dan fakta temuan dilapangan peneliti melihat dalam pelaksanaan sosialisasi dan pembinaan yang dilakukan Dinas Kebudayaan dan Pariwisata sebagai dinamisator terhadap seniman wayang golek cukup minim sekali dengan pelaksanaan 3 sampai 4 kali dalam kurun waktu 1 tahun. Seniman wayang golek menyampaikan aspirasi kepada Dinas Kebudayaan dan Pariwisata agar lebih ditingkatkan pembinaan terhadap para seniman agar bisa berdaya saing dan peningkatan ekonomi bagi seniman wayang golek.

Namun, aspirasi yang dikemukakan oleh seniman wayang golek terhadap Dinas Kebudayaan dan Pariwisata belum menerima respon yang baik. Hasil observasi yang peneliti lakukan pun menunjukan kurangnya sosialisasi dan pembinaan yang membuktikan bahwa Dinas Kebudayaan dan Pariwisata Kabupaten Bandung Barat kurang optimal dalam melaksanakan perannya. Hal tersebut dibuktikan dengan semakin berkurangnya eksistensi pagelaran kesenian wayang golek di Kabupaten Bandung Barat.

Upaya-upaya pembinaan senantiasa dilakukan oleh Dinas Kebudayaan dan Pariwisata melalui bimtek (bimbingan teknis). Bimtek ini dilakukan di masing-masing kecamatan di wilayah Kabupaten Bandung Barat. Dalam pelaksanaanya, Dinas Kebudayaan dan Pariwisata Kabupaten Bandung Barat dibantu oleh Pepadi Kabupaten Bandung Barat. Sehingga dalam hal ini peneliti melihat bahwa Dinas Kebudayaan dan Pariwisata Kabupaten Bandung Barat sebagai dinamisator telah menjalankan program yang telah ditetapkan sebelumnya, namun dalam pelaksanaannya memang belum mencapai hasil yang maksimal. Kuantitas dan kualitas sosialisasi serta pembinaan amat menentukan bagaimana hasil dari upaya pelestarian kesenian wayang golek yang dilaksanakan. Aspirasi dari seniman wayang golek terhadap Dinas Kebudayaan dan Pariwisata diharapkan ditinjau dan melakukan kunjungan 
lapangan terkait problematika dalam upaya pengembangan dan pelestarian kesenian wayang golek yang ada di Kabupaten Bandung Barat.

\section{Pemerintah Sebagai Fasilitator}

Pemerintah pada umumnya dalam melaksanakan penyelenggaraan pemerintahannya memberikan pelayanan dan fasilitas bagi masyarakatnya. Baik fasilitas umum maupun fasilitas khusus, begitupun dalam penyediaan fasilitas bagi pelestarian kesenian. Pada dasarnya pemerintah sebagai fasilitator dan penyedia layanan bagi masyarakat. Peran Dinas Kebudayaan dan Pariwisata sebagai fasilitator adalah menciptakan perkembangan yang baik bagi pelaksanaan pelestarian kesenian wayang golek untuk menjembatani berbagai kepentingan seniman serta masyarakat dalam mengoptimalkan pelestarian kesenian wayang golek di Kabupaten Bandung Barat. Sebagai fasilitator, Dinas Kebudayaan dan Pariwisata Kabupaten Bandung Barat bergerak dibidang pendamping melalui sosialisasi, pembinaan dan memfasilitasi pendanaan serta sarana dan prasarana yang diperlukan dibidang pelestarian kesenian wayang golek. Dinas Kebudayaan dan Pariwisata berupaya agar seniman wayang golek mampu untuk merencanakan, membangun serta mengelola berbagai sarana dan prasarana yang diberikan oleh Pemerintah. Hal ini ditujukan agara pelestarian kesenian wayang golek dapat diselenggarakan dengan seefektif dan seefisien mungkin.

a. Pembangunan Untuk Pelestarian

Pembangunan merupakan sebuah proses perubahan yang terus menerus yang dilakukan untuk menuju perubahan yang lebih bak berdasarkan pada norma- norma tertentu. Pembangunan yang berhasil disebabkan karena konsep perencanaan yang tersusun secara sistematis dan direalisasikan sesuai dengan prosedur yang telah ditetapkan. Peran Dinas Kebudayaan dan Pariwisata Kabupaten Bandung Barat dalam dimensi pembangunan untuk pelestarian ini direalisasikan dengan pengadaan tempat penyelengaraan pagelaran kesenian wayang golek serta memberikan bantuan kepada setiap padepokan berupa alat-alat perlengkapan untuk menunjang pagelaran kesenian. Berdasarkan hasil wawancara peneliti bersama Bapak Usup, menjelaskan bahwa:

"Bandung Barat belum memiliki bangunan khusus sebagai tempat penyelenggaraan kesenian, namun penyelenggaraan kesenian biasa dilakukan di depan halaman Pemkab Bandung Barat, Pembangunan gedung kesenian sebenarnya sudah diwacanakan jauh-jauh hari, namun anggaran belum memadai 
serta pemilihan tempat untuk pembangunan belum kondisional."

Dalam penyelenggaraan festival kesenian wayang golek, maupun pasanggiri Pemerintah Kabupaten Bandung Barat belum memiliki tempat pertunjukan khusus kesenian seperti gedung kesenian, melihat pendapatan asli daerah belum diatas rata- rata serta kunjungan dari wisatawan luar yang cukup minim mengakibatkan belum tersedianya tempat pertunjukan khusus. Dalam penelitian yang dilakukan pada saat dilapangan peneliti mendapatkan temuan data terkait pemberian bantuan peralatan kesenian wayang golek. Hal tersebut dapat dilihat pada tabel berikut:

Tabel 3

Data Realisasi Pemberian Bantuan

Peralatan Kesenian Wayang Golek di Kabupaten Bandung Barat Tahun

2016-2017

\begin{tabular}{|c|c|c|c|c|}
\hline NO. & $\begin{array}{c}\text { JENIS PERALATAN } \\
\text { KESENIAN }\end{array}$ & $\begin{array}{c}\text { JUMLAH } \\
\text { TAHUN } \\
\mathbf{2 0 1 6}\end{array}$ & $\begin{array}{c}\text { JUMLAH } \\
\text { TAHUN } \\
\mathbf{2 0 1 7}\end{array}$ & $\begin{array}{c}\text { BIDANG } \\
\text { KESENIAN }\end{array}$ \\
\hline 1 & $\begin{array}{c}\text { Peralatan Kesenian } \\
\text { Wayang Golek }\end{array}$ & 1 Set & 1 Set & $\begin{array}{c}\text { Seni } \\
\text { Pedalangan }\end{array}$ \\
\hline
\end{tabular}

Sumber: Dinas Kebudayaan \& Pariwisata Kab. Bandung Barat, 2017

Sebagaimana dapat dilihat pada tabel diatas bahwa pemberian bantuan peralatan kesenian wayang golek yang diberikan oleh Dinas Kebudayaan dan Pariwisata sama sekali tidak ada peningkatan dari tahun 2016 sampai tahun 2017. Berdasarkan hasil observasi, peneliti melihat bahwa rencana kerja Dinas Kebudayaan dan Pariwisata Kabupaten Bandung Barat belum optimal. Untuk melengkapi data hasil observasi tersebut, peneliti melakukan wawancara dengan Pak Toyo selaku pimpinan padepokan wayang golek pancanaka, beliau menjelaskan bahwa: "bantuan dari pemerintah terkait (dalam hal ini Dinas Kebudayaan dan Pariwisata) seperti peralatan penunjang pagelaran sama sekali belum diberikan." Sementara itu, peneliti juga melakukan wawancara dengan Bapak Cep Syahroni di Padepokan Giri Wibawa I pada taggal 20 Januari 2018 yang mengatakan bahwa: "Dinas Kebudayaan dan Pariwisata memang pernah memberikan bantuan berupa gamelan, namun 
itupun sekitar tahun 2015, sampai saat ini belum pernah ada bantuan kembali".

Berdasarkan hasil wawancara dan observasi serta indikator fasilitator, peneliti melihat bahwa peran Dinas Kebudayaan dan Pariwisata sebagai fasilitator dalam upaya pembangunan gedung kesenian hanya baru rencana saja, namun hal ini belum direalisasikan karena terbatasnya anggaran. Sehingga, anggaran merupakan salah satu fakta penunjang pelestarian kesenian wayang golek. Perencanaan dapat terlaksana jika anggaran tersedia dalam mengaplikasikan rencana yang telah ditetapkan tersebut. Dalam penyediaan sarana dan prasarana Dinas Kebudayaan dan Pariwisata sebagai fasilitator merencanakan strategis untuk peningkatan kunjungan wisatawan agar meningkatnya pendapatan asli daerah Kabupaten Bandung Barat sehingga dapat mewujudkan pembangunan gedung kesenian untuk penyelenggaraan kesenian wayang golek, dapat meningkatkan ekonomi masyarakat serta seniman wayang golek yang ada di Kabupaten Bandung Barat.

b. Mengembangkan potensi

Daerah merupakan bagian dari suatu wilayah sebagai teritorial yang ditentukan atas pengertian, batasan dan wewenang administratif yang didasarkan pada peraturan perundang-undangan. Setiap daerah tentunya memiliki potensinya masing-masing untuk meningkatkan pembangunan daerah dan menjaga kelestarian yang ada di daerah tersebut. Pengembangan potensi merupakan salah satu langkah yang perlu dilakukan oleh Dinas Kebudayaan dan Pariwisata Kabupaten Bandung Barat dalam upaya pelestarian kesenian wayang golek. Pengembangan potensi dilakukan untuk menarik minat serta pasrtisipasi pengunjung asli daerah maupun wisatawan terhadap wayang golek. Dinas Kebudayaan dan Pariwisata Kabupaten Bandung Barat sering melakukan upaya pelestarian kesenian wayang golek dengan cara memanfaatkan arus wisata. Arus wisata merupakan salah satu modal yang cukup besar dalam meningkatkan minat masyarakat serta wisatawan pada kesenian wayang golek. Berdasarkan hasil wawancara peneliti dengan Bapak Usup yang mengatakan bahw :

"pengembangan potensi pada kesenian wayang golek sering dilakukan melalui promosi kebeberapa daerah lain dengan memberikan alur pagelaran yang memiliki ciri khas tersendiri, hal tersebut diharapkan dapat memikat minat pengunjung yang menontonnya". 
Dalam pengembangan potensi pelestarian kesenian wayang golek Dinas Kebudayaan dan Pariwisata sering menghadiri undangan-undangan diluar daerah, disamping itu Dinas Kebudayaan dan Pariwisata memanfaatkan keadaan untuk mempromosikan potensi kesenian wayang golek yang ada di Kabupaten Bandung Barat, yang mempunyai ciri khas tersendiri.

Dari hasil observasi yang peneliti lakukan juga dapa terlihat bahwa Dinas Kebudayaan dan Pariwisata Kabupaten Bandung Barat sebagai fasilitator telah melaksanakan upaya promosi sesuai dengan program, namun dalam hal ini dalam bentuk pagelaran wayang golek masih kurang diberikan pada dalang asli daerah, hal demikan ditunjukan dengan undangan acara akbar seperti ulang tahun pemkab yang tidak mengundang dalang yang tersebar di Kabupaten Bandung Barat, melainkan mengundang dalang dari daerah lain.

Berdasarkan hasil wawancara dan observasi diatas serta indikator fasilitator, peneliti melihat bahwa pengembangan potensi yang dilakukan oleh Dinas Kebudayaan dan Pariwisata sebagai fasilitator kurang diselenggarakan dengan optimal. Media promosi hanya sebatas diselenggarakan melalui pagelaran yang minim sekali sarana dan prasarananya, serta upaya promosi pun tidak memaksimalkan segala potensi yang tersedia didaerah, seperti dalang yang handal dan lain sebagainya. Sehingga dalam hal ini menunjukan bahwa peran Dinas Kebudayaan dan Pariwisata dalam pengembangan potensi harus ditunjang dengan media promosi serta penghargaan setinggi-tingginya pada dalang di daerah asli. Dinas Kebudayaan dan Pariwisata dalam melakukan kunjungannya ke beberapa daerah dengan mempromosikan kesenian wayang golek sebagai potensi wisata bagi Kabupaten Bandung Barat seharusnya diimbangi dengan penyediaan fasilitas-fasilitas penunjang untuk penyelenggaraan kesenian wayang golek agar minat wisatawan lebih meningkat serta penghargaan bagi dalang asli daerah diberikan setidaknya 1 tahun sekali dengan beberapa kriteria yang ditentukan.

\section{KESIMPULAN}

Berdasarkan penelitian dan pembahasan sebagaimana yang diuraikan sebelumnya mengenai Peran Dinas Kebudayaan dan Pariwisata Kabupaten Bandung Barat Dalam Pelestarian Kesenian Wayang Golek Di Kabupaten 
Bandung Barat, maka peneliti mengambil kesimpulan sebagai berikut:

1. Pemerintah sebagai regulator

Peran Dinas Kebudayaan dan Pariwisata Kabupaten Bandung Barat dalam upaya pelestarian kesenian Wayang Golek kurang optimal karena belum ada regulator yang secara khusus mengatur secara teknis tentang tata cara pelaksanaan pelestarian kesenian Wayang Golek. Penentuan arah dan tujuan belum diselenggarakan sebagaimana dengan tujuan yang telah ditetapkan sebelumnya.

a. Peraturan Pelestarian Kesenian

Program-program yang dilaksanakan oleh Dinas Kebudayaan dan Pariwisata Kabupaten Bandung Barat belum dapat memberikan hasil yang maksimal dalam upaya pelestarian kesenian Wayang Golek salah satunya belum adanya peraturan yang mengatur secara khusus pelestarian kesenian Wayang Golek agar menjadi acuan kebijakan yang dilakukan oleh Dinas Kebudayaan dan Pariwisata.

2. Pemerintah sebagai fasilitator

a. Pembangunan untuk pelestarian

Dinas Kebudayaan dan Pariwisata Kabupaten Bandung Barat belum memberikan fasilitas berupa bangunan kesenian yang menunjang dalam penyelenggaraan pagelaran Wayang Golek. Penyelenggaraan pagelaran Wayang Golek masih memanfaatkan halaman Pemkab Bandung Barat. Anggaran yang minim menjadi salah satu alasan belum adanya pembangunan yang ditujukan dalam upaya pelestarian kesenian Wayang Golek tersebut.

\section{DAFTAR PUSTAKA}

\section{Buku Teks}

Sugiyono. 2014. Metode Penelitian Kuantitatif dan Kualitatif. Bandung: Alfabeta 
Moleong, Lexy J. 2008. Metodologi Penelitian Kualitatif. Bandung: Remaja Rosdakarya.

Ndraha, Taliziduhu. 2003. Kybernology 1 \& 2 (Ilmu Pemerintahan Baru). Jakarta: Bhineka

Rasyid, Ryaas. 1996. Makna Pemerintahan; Tinjauan Dari Segi Etika dan Kepemimpinan. Jakarta: PT. Yarsif Watampone

Syafiie, Inu Kencana. 2011. Ekologi Pemerintahan. Bandung: PT. Pustaka Reka Cipta

Bagir, Manan, 2002. Menyongsong Fajar Otonomi Daerah, PT Gramedia Pustaka Utama

Widjaja H. W. 2002. Otonomi Daerah dan Daerah Otonom. Jakarta: PT. Raja Grafindo Persada

Pendit, Nyoman S. 2006. Ilmu Pariwisata Sebuah Pengantar Perdana. Jakarta: PT. Pradnya Pramita

Sulaeman, Munandar. 1992. Ilmu Budaya Dasar, Bandung: PT. Eresco

Koentjaraningrat. 1990. Pengantar Ilmu Antropologi. Jakarta: PT. RinekaCipta

Soekanto, Soerjono. 2000. Sosiologi Suatu Pengantar. Jakarta: PT. Raja Grafindo Persada

Jazuli M. 2014. Sosiologi Seni. Yogyakarta: PT. Graha Ilmu

\section{Dokumen - Dokumen}

Peraturan Pemerintah Republik Indonesia Nomor 84 Tahun 2000 Tentang Pedoman Organisasi Perangkat Daerah

Undang-Undang Nomor 23 Tahun 2014 Tentang Pemerintah Daerah UndangUndang Nomor 10 Tahun 2009 Tentang Kepariwisataan

Peraturan Daerah Provinsi Jawa Barat Nomor 15 Tahun 2014 Tentang Perubahan Atas Peraturan Daerah Provinsi Jawa Barat Nomor 6 Tahun 2003 Tentang Pemeliharaan Kesenian

Peraturan Daerah Kabupaten Bandung Barat Nomor 4 Tahun 2012 Tentang Rencana Induk Pembangunan Kepariwisataan Kabupaten Bandung Barat

Peraturan Bupati Bandung Barat Nomor 19 Tahun 2009 Tentang Tugas Pokok Fungsi dan Rincian Tugas Dinas Kebudayaan dan Pariwisata

Laporan Akuntabilitas Kinerja Instansi Pemerintah (LAKIP) Dinas Kebudayaan dan Pariwisata Kabupaten Bandung Barat Tahun 2016

\section{Jurnal}

Adillah, Rizky. 2014. Peran Dinas Pariwisata Dalam Mempromosikan Objek Wisata Pada Wisatawan Di Kota Bandung. Bandung: Universitas Komputer Indonesia

Nurgiyantoro, Burhan. 2011. Wayang Dan Pengembangan Karakter Bangsa. Yogyakarta: FBS Universitas Negeri Yogyakarta 
Monika, Ika. 2014. Kebijakan Pemerintah Daerah Dalam Pelestarian Kesenian Tradisional Di Kota Makasar. Makasar : Universitas Hasanuddin

\section{Website}

Bharatanews, 2017. Festival Seni Budaya. http://bharatanews.id/2016/10/25/dukungan-untuk-festival-tahunan-senibudaya-kabupaten-bandung-barat-masih-kurang/ (Diakses pada hari Selasa, tanggal 7 November 2017 Pukul 19:30 Wib)

Profil Dinas Kebudayaan dan Pariwisata.2018 http://bandungbaratkab.go.id/profile/dinas-pariwisata-dan-

kebudayaan(Diakses pada hari Jum'at, tanggal 16 Februari 2018 Pukul 06:15 Wib)

UNESCO. Budaya Indonesia.2017

http://www.about-indonesia.com/2017/03/28/5-heritage-cultures-ofindonesia-unesco-recognition/ (Diakses pada hari Kamis, tanggal 23 November 2017 Pukul 21:30 Wib) 